and must agree to observe the rules establishei for the management of the reading-room.

6. In accordance with a legal statute, a library fee, payable in advance, is collected from every member at the beginning of each semester. For ordinary members, to each of whom a private drawer in the reading-loom may bo assigned, the fee is five marks, and for other members it is three marks. In addition, there is a deposit of three marks required from each member receiving a key, and returnable upon the surrender of the key.

7. The collection of these fees and the maintenance of order in the reading-room are in charge of the librarian, under the supervision of the directors. Members are required to obey his instructions. Further regulations will be announced by means of notices in the reading-room.

The directors of the seminary of mathematics and physics: Riecke, Schering, Votgt, Klein, Soher, W eber.

\title{
NOTES.
}

A Regular meeting of the New York Mathematical SocIETY was held Saturday afternoon, November 4, at halfprst three o'clock, the president, Dr. McClintock, in the chair. Mr. Isuac Hodges Turrell of Cincinnati, Ohio, having been duly nominated, and being recommended by the council, was elected a member. Professor Fletcher Durell read a paper entitled "Application of the new education to the differentiul and integral calculus," in which he advocated the presentation of the first principles of the calculus from an almost purely geometrical point of view.

The National Academy of Sciences met in the Capitol at Albany, Norember $7-9$. The papers presented included one by Dr. S. C. Chandler, entitled "Additional researches on the motion of the earth's pole." Dr. Chandler finds that the most recent observations obtainable (some still unpublished) confirm the law deduced by him. He showed that the two separate motions of the pole both take place from west to east. Dr. Chandler's paper was discussed by Professors Hall, Newcomb and Boss. They all expressed themselves as now favoring the truth of Dr. Chandler's law of variations. Professor C. S. Hastings read a paper on "A new form of telescopic objective, as applied to the twelveinch equatorial of the Dudley Observatory." The principal characteristics of this instrument are: first, that one of the 
"ghosts" is made to coincide with the focal plane, thus rendering it harmless; and second, that the transformation from a visual to a photographic telescope is accomplished by substituting a second glass for one of the lenses of the visual combination, instead of adding a third lense. Professor Asaph Hall read a short paper on "Double stars." Professor Charles L. Doolittle (introduced by Professor Boss) communicated a paper, "Latitude determinations at the Sayre Ob. servatory," but was unable to be present in person.

During the afternoon of November 8 the members of the Academy visited the new Dudley Observatory by invitation. The completed observatory was opened for inspection, and an address was made by Professor Simon Newcomb. H. J.

OBERLIN COLLEGE has secured for its library the collection of mathematical books sent by B. G. Teubner, of Leipzig, to the mathematical section of the German university exhibit at the Chicago Exposition. This collection contains over 150 important modern treatises, in addition to complete sets of the Mathematische Annalen, Zeitschrift für Mathematik und Physik, and Zeitschrift fïr mathematischen und naturwissenschaftlichen Unterricht.

THE annual meeting of the London Mathematical Society was held on November 9. The officers and council elected for the coming year are: President, A. B. Kempe; Vice-Presidents, A. B. Basset, Prof. Elliott, Prof. Greenhill; Treasurer, J. Larmor; Secretaries, M. Jenkins, R. Tucker; other members of the Council, Lieut.-Col. J. R. Campbell, Lient.-Col. A. J. Cunningham, A. R. Forsyth, J. W. L. Glaisher, Prof. M. J. M. Hill, E. W. Hobson, A. E. H. Love, Major MacMahon, J. J. Walker. The De Morgan medal, which had been awarded to Professor Klein, was presented, in his absence, to Professor Greenhill and Dr. Forsyth, who had been appointed to receive it for him, and who made replies in his behalf.

A REPORT from the committee appointed to receive subscriptions for the Gauss-Weber memorial at Göttingen announces that the total amount of contributions will probably reach 25,000 marks.

DR. J. H. Bord has accepted a position as tutor in the department of mathematics at the University of Chicago.

T. S. F.

Professor G. E. Fishrer and Dr. Schwatt, of the University of Pennsylvania, are preparing an English translation of H. Durège's " Elemente der Theorie der Funktionen einer 
complexen veränderlichen Grösse." The translation will be supplemented by a considerable amount of additional matter and by the insertion of numerous exercises. B. G. 'Teubner, of Leipzig, is the publisher. The book is expected next summer.

A. $\mathbf{z}$.

\section{NEW PUBLIOATIONS.}

\section{HIGHER MATHEMATICS.}

BrNder (W.). Über Plancurven vierler Ordnung vom Geschlechte $p=$ 1 und ihre typischen Formen. [Progr.] Wiener-seustudt, $180 \overline{3}$. 8ro. 64 pp. 1 plate.

Breijek (II. G.). De grondvormen der krommen van de 3e klasse. [Diss.] Amsterdum, 1898. 8vo. 8 aud $72 \mathrm{pp}$.

Brokcker (H.). Die Periodicitatsmoduln der Abel'schen Integrale erster Gattung als Functiouen eines Parnmeter's aufgefinst fur den Full ciner Riemanu'schen Fläche, deren Gleichung in Buzug auf die eine Vurriabele binomisch ist. Berlin, 1893 . 8vo. $55 \mathrm{pp} .1$ plate.

Mk. 1.50

DEDEKIND (R.). Was sind und was sollen die Zahlen? 2te Auflage. Brannschweig, Vieweg, 1898. 8vo. 19 and 58 pp. Mk. 1.60

Flevir (H.). L Lanalyse infinitésimale suns limites ni infiniment petits. Patis, 1893.8 8o. $40 \mathrm{pp}$.

Ilk. 2.00

Gotirsat (E.). Torlesungeu uber die Integration der partiellen Differentialgleichmmgen erster Ordunng, gehalten an der Faculté des Sciences zu Paris, bearbeitet von C. Bunrlet. Autorisirte deutsche Ausgube vou $H$. Ilaser. Mit einem Begleitwort vou S. Lie. Leip. zin, Teubuer, 1893. 8vo. 12 and $416 \mathrm{pp}$.

Mlk. 10.00

HaRst (A. D. VAN DER). Bijdrage tot de theorie en toepassing der kromlijuige cöordinaten. [Diss.] Leillen, 1893. 4to. 10 and $55 \mathrm{pp}$.

Jamisucn ther die Fortschritte der Mrathematik, begründet von C. Onrtmaun, herausgegeben von E. Lampe. Vol. 22 (Jahrgaug 1890), 3tes Heft. Berlin, Reimer, 1893. $8 \mathrm{vo} .68 \mathrm{pp}$. and pp. $84 y_{-}$ 1313 .

Mk. 13.00

Jocuvick (W.). Det vigtigaste af analytiska Geometrien. Stockbolm, 1893. 8vo. $136 \mathrm{pp}$.

Mlk. 5.00

KässomRek (L.). Die linear-mubhangigen quadratischen Relationen $z$ wischen den zum Kurvengeschlecht $p=8$ gehörigen For'men $\phi$. [Progr.] Nïrnberg, 1893. 8vo. $43 \mathrm{pp}$.

Killing (W). Finführung in die Grundlagen der Geometrie. Band I. Paderborn, 1893. 8vo, 10 and $35 \%$ pp. Illustrated. Mk. 7.00

KLEs (F:). On Riemann's theory of algebraic functions and their integrals. A supploment to the usual treatises. 'Translated from the German with the author's permission br Frances Hardcastle. London and New York Nacmillan. 1893 . 8vo. 76 pp. $\$ 1.40$ 